Primer registro de varamiento del

Zifio de Cuvier (Ziphius cavirostris) en

Isla Guadalupe, México

\title{
First stranding record of a Cuvier beaked whale (Ziphius cavirostris) at Isla Guadalupe, Mexico
}

\author{
Juan Pablo Gallo-Reynoso ${ }^{1^{*}}$ and Edgar Mauricio Hoyos-Padilla ${ }^{2}$
}

\begin{abstract}
'Centro de Investigación en Alimentación y Desarrollo, A. C. Unidad Guaymas, Carretera al Varadero Nacional, km 6.6, Las Playitas, Guaymas, 85480, Sonora, México. E-mail: jpgallo@ciad.mx (JPGR).

2Pelagios-Kakunjá A.C. Sinaloa 1540, 23070, La Paz, Baja California Sur, México. E-mail: amuakua@gmail.com (EMHP).

${ }^{*}$ Corresponding author.
\end{abstract}

\begin{abstract}
Introduction: A calf of a Cuvier beaked whale, Ziphius cavirostris, was found stranded at Isla Guadalupe, Mexico where this species have been observed before.

Methods: A detailed necropsy was conducted to report the plausible stranding causes. The individual was measured.

Results: The female calf was apparently a month old individual and was still suckling. Body temperature was still warm, with no pupillary reaction or artery pulse at the inner blowhole and at the fluke major arteries. The stomachs contained milk in different degradation stages (fresh to semi-digested).

Discussion: Necropsy of the calf did not show any plausible indication about its death, such as major wounds that indicate predation, trauma, ulcers or infections, only the presence of a small bubbling blood effusion together with some epithelial and muscle tissue masses extruding from the urogenital opening. No gas related trauma such as decompression could be confirmed due that we did not have the means to measure gas presence on epithelial tissues. The probable cause of dead was hypoxia.
\end{abstract}

Key words: Calf stranding; cuvier beaked whale; Isla Guadalupe; Ziphius cavirostris.

\section{Introduction}

Cuvier's beaked whale (Ziphius cavirostris G. Cuvier 1823) is observed around oceanic islands such as Isla Guadalupe, México (Gallo-Reynoso and Figueroa-Carranza 1995; 1998; 2005; Cárdenas-Hinojosa et al. 2012; Schorr et al. 2014). This species was first described by G. Cuvier, based on a partial skull collected in 1804 near Fos-sur-Mer, in the Mediterranean coast of France (Cuvier 1823 in Podesta et al. 2006). Beaked whales live in open waters and are associated with high relief bottoms, deep canyons and steep slopes (Heyning 1989), characteristics that are found at Isla Guadalupe.

Isla Guadalupe ( $29^{\circ} 00^{\prime} \mathrm{N},-118^{\circ} 15^{\prime} 30^{\prime \prime} \mathrm{W}$ ) is located $240 \mathrm{~km}$ west of Baja California, Mexico. The island lies within the California Current with an average sea surface temperature of $18^{\circ} \mathrm{C}$ (range: 16 ${ }^{\circ} \mathrm{C}$ spring, $20^{\circ} \mathrm{C}$ summer; Lynn and Simpson 1987). Depths of 3,600 m or more surround the island. The coastline physiography is composed of loose basaltic rocks and boulders bounded by towering 
cliffs, with numerous crevices and caves (Pierson 1987). The orientation of the island ( $\mathrm{N}-\mathrm{S}$ ) and its elongated shape (35 km long and $6.5-9.5 \mathrm{~km}$ wide) act as a barrier against the flow of the current that produces a series of swirls at different depths (Berdegué 1957).

The presence of female - calf pairs of Cuvier's beaked whales at Isla Guadalupe have been observed by us, we have recorded on video three different females with calves on September $3^{\text {rd }}$, October $13^{\text {th }}$ and $26^{\text {th }} 2009$ and by Cardenas-Hinojosa et al. (2009). The aim of this paper is to report the stranding, measurements and cause of death of one calf at Playa Dos Arroyos (Twin Canyons) $\left(29.10208^{\circ} \mathrm{N},-118.27486^{\circ} \mathrm{W}\right)$. Based on the diagnostic characteristics described by Leatherwood et al. (1983), such as the comparison of the shape of the head with a bulky melon that descends toward the tip of the beak, the concave form of the mouth, the presence of two throat creases (Figure 1) and the position of the dorsal fin, found at two thirds of the total length (measured from the tip of the beak to the median notch in the flukes), we determined the species as a Ziphius cavirostris female calf. There were no other beaked whales observed that day.

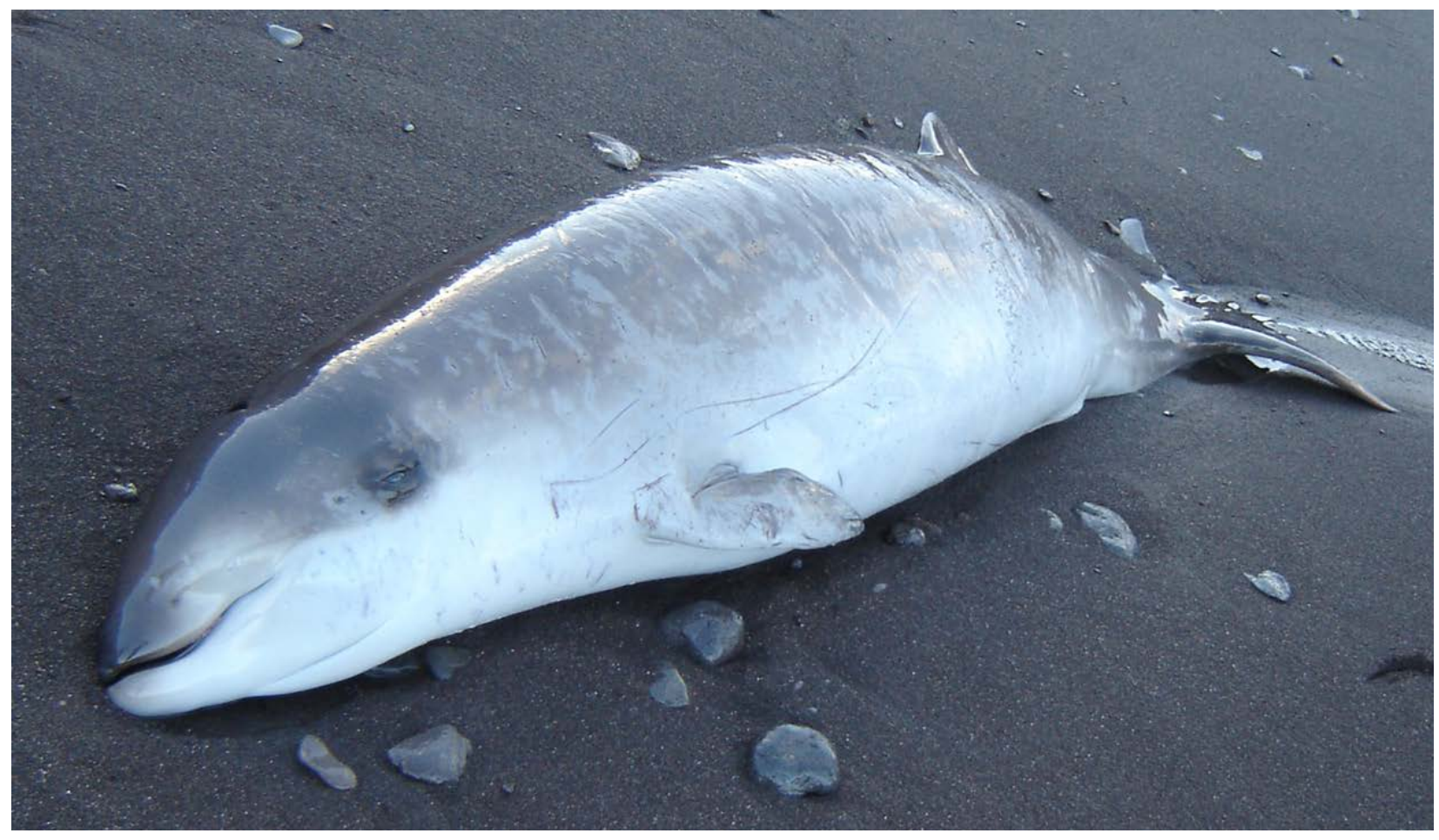

Figure 1. Female calf Ziphius cavirostris, stranded at Playa Dos Arroyos (Twin Canyons), Isla Guadalupe, Mexico. Note the presence of two throat creases and fetal folding marks. March 2, 2010 (Photo J.P. Gallo-Reynoso).

This calf probably died minutes before our arrival, the body temperature was warm (felt with the fingers through the latex glove inside the blowhole), therefore we tried to reanimate the individual with cardio-pulmonary massage, with pressure over the thoracic area, after five minutes there was no response and no expulsion of air or water from the lungs through the blowhole, although there was a small bloody-foamy efflux via the anus, which we did not expect. It was also surprising to find that the lungs were apparently collapsed and that the animal's core temperature was apparently normal but with no pulse that could be felt by placing pressure on the major arteries of the flukes. The inside of the blowhole was pressured again to see if there was any pulse, afterward it was completely obstructed with a fist to see if there was any muscle reaction or breathing spasm - which was negative. Finally we also observed the gums (which are pink if there is any blood circulation, and pale if blood circulation is absent) we found the 
gums were pale; the tongue was dark-blue which presumed a cyanotic state. All these findings corroborated the death of the calf.

Further inspection, revealed that the eyes were open, humid, still and with no apparent pupillary reaction. The body did not present with rigor mortis and was still flaccid. Skin coloration was creamy-white in the ventral area from the tip of the lower beak under the eyes and to the flanks, ending at the medial area of the caudal peduncle before the insertion of the flukes. The melon dorsal area was dark grayish - copper and in some portions bluish gray, darker around the eyes. The dorsal fin was of a gray - copper color and not tall, but very falcated. Flukes were dark gray, while pectoral flippers were gray in their distal part of the dorsal surface and creamy-white on the ventral surface (Figure 1). The blowhole was wide and crescentic. There were no erupted teeth. The surface of the body presented scarring with some linear scars that were shallower than others, presumably made by an adult male of the same species (Figure 1), these scars are common and are produced by the interspecific interaction between the individuals of a pod (Heyning 1989).

A weight of around $200 \mathrm{~kg}$ was estimated for the calf. The total length of the calf was 2.64 m (Table 1), according to Leatherwood et al. (1983) and Heyning and Mead (2009) corresponds to a newborn calf. Fetal folds were still somewhat perceptible (these are evident in newborns; Figure 1). Both body sides were carefully reviewed, there were no injuries that could link the death to a white shark (Carcharodon carcharias) attack; individuals of this shark species are numerous in this area of the island, there are about 200 known individuals (Hoyos-Padilla 2009). However, we noted the presence of a healing round wound on the left flank suggestive of a cookie cutter shark Isistius brasiliensis (Figure 2); a species that commonly attacks three species of pinnipeds and several species of cetaceans near the island (Gallo-Reynoso and Figueroa-Carranza 1992, 2005; Gallo-Reynoso et al. 2005a, and 2005b) and that have been reported to attack this species elsewhere (Jones 1971; Pérez-Zayas et al. 2002). The wound was more than a week old, suggesting that the calf should be older than a week. Therefore, we estimate that this calf was close to a month of being born. A detailed observation of the body surface did not show any cause of apparent death; there were no evident signs of trauma or infection (such as foul smell, ulcers or suppuration that might be present in the blowhole, mouth, throat, anus or the urogenital opening). The unusual finding that was noted, was the presence of a small bloody effusion together with some epithelial and muscle tissue masses that were extruding from the urogenital opening, showing probable signs of acute decompression.

A necropsy was performed with an initial incision along the abdominal axis, from the solar plexus to the urogenital opening, the second one from the solar plexus to the dorsal portion near the pectoral flipper, and the third one from the mid-ventral area (at sternum) to the dorsal portion before the dorsal flipper to open the abdominal cavity. We removed the cutaneous, subcutaneous tissues and the fat layer to get access to the thoracic and abdominal cavities. There were no evident anomalies, such as internal lacerations, broken bones, ruptured viscera, ulcers, bruises, parasites or damaged blood vessels, additionally there was no foul smell noted.

We conducted a thorough review of the following organs:

Lungs. Both were collapsed, there was no presence of air or water inside of them, there was a certain bubbling probably produced by the surfactant that lubricates and prevents alveolar collapse while diving. There was no suppuration that could indicate an infection, swelling, blood or any other liquid present; there were no lesions on the pleura or alveoli, or foreign bodies present.

Heart. The cardiac muscle was normal in appearance and size, no blood leaking from the surrounding vessels or the coelom that covers it. 
Liver. No gross alterations, parasites or cists noted.

Kidneys. Normal in size, multilobed, no apparent hemorrhages, parasites, kidney stones or any signs of malformations were found.

Stomachs. No presence of ulcers, hemorrhages, bruises or lacerations; they were filled with milk, which allowed to determine that the calf had recently suckled before stranding. There was no indication that the calf had ingested solid food; there were no rests of squids (beaks), fishes (bones, vertebrae, scales or otholits, etc.), crustaceans (exoskeleton), or any other parts that make up the food for this species (sensu Podesta and Meotti 1991).

Table 1. Measurements of the Cuvier's beaked whale female calf.

\begin{tabular}{|c|c|}
\hline Total Length & 264.2 \\
\hline Length from the mouth junction to the anterior insertion of the right pectoral flipper & 157.5 \\
\hline Length of the anterior insertion of the dorsal fin to the fluke's notch & 111.8 \\
\hline Farthest length of the right pectoral flipper (apical) from the anterior insertion & 35.6 \\
\hline Length of the right pectoral flipper, posterior border & 28.5 \\
\hline Length from the center of the eye to the mouth junction & 16.5 \\
\hline Width of the ocular opening (eye) & 1.78 \\
\hline Length of the ocular opening & 3.05 \\
\hline Length from the tip of the beak to the right side mouth junction & 20.3 \\
\hline Length of the right throat crease & 15.2 \\
\hline Length from the center of the eye to the anterior insertion of the dorsal fin & 34.3 \\
\hline Length from the mouth to the anterior insertion of the pectoral flipper & 157.5 \\
\hline Length of dorsal fin & 94 \\
\hline Height of dorsal fin & 14 \\
\hline Width of dorsal fin & 175.3 \\
\hline Length from tip of the beak to the urogenital opening & 170.2 \\
\hline Width of fluke & 74.9 \\
\hline Length of the left fluke & 33 \\
\hline Height of the caudal peduncle & 25.4 \\
\hline Length from the center of the blowhole to the beak point & 32.4 \\
\hline Width of the blubber layer in the left flank & 2.5 \\
\hline Width of the blubber layer above the right pectoral flipper & 3.05 \\
\hline Width of the blubber layer at the head & 3.6 \\
\hline Length of the cookiecutter shark bite & 5.7 \\
\hline Height of the cookiecutter shark bite & 4.3 \\
\hline Axilar circumference & 137.2 \\
\hline Circumference at umbilicus & 146.1 \\
\hline Circumference at the blowhole & 97.8 \\
\hline Circumference anterior to the right fluke & \\
\hline Circumference at the center of the anus & \\
\hline
\end{tabular}


Intestines (from pylorus to anal opening). Milk was found in several stages of digestion, there were no obstructions, or foul smell, or ulcers of any type. We noted that at the end of the intestine the presence of a small bloody and bubbling effusion together with some epithelial and muscle tissue masses that were extruding from the urogenital opening indicating a probable rupture due to gas embolism, showing probable signs of acute decompression.

Samples were taken from the above mentioned organs, and additionally of skin, blubber, muscle, bone, brain and milk (fresher milk found in the first stomach). These samples are deposited at CICIMAR-IPN (La Paz, Mexico) for their study. The head was sectioned and separated from the rest of the body, and it was buried to be retrieved later to inspect the skull and to observe if tympanic bullae or the mandibles were fractured, due to decompression while quickly ascending to the surface. The head is now at the same institution (CICIMAR).

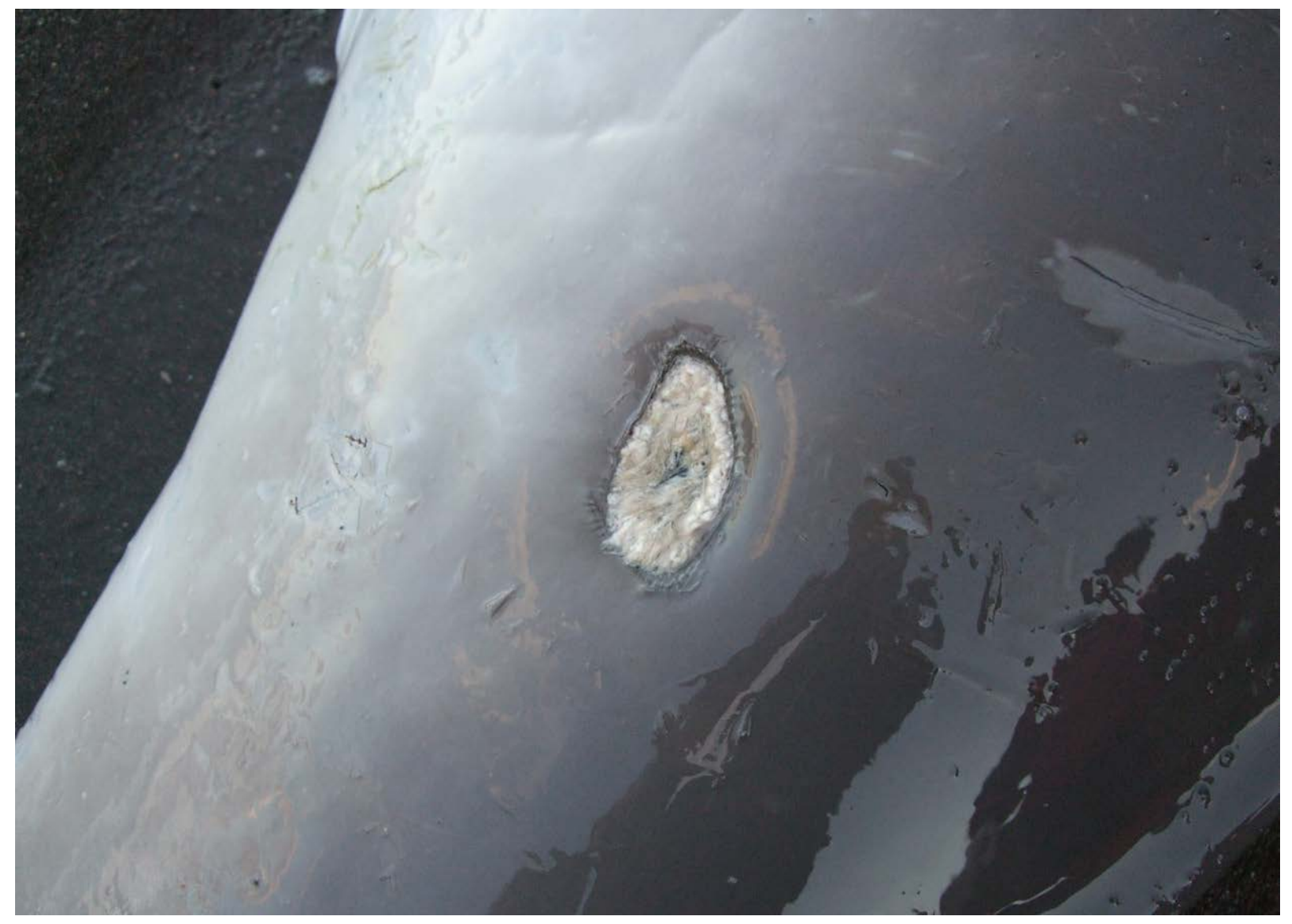

Figure 2. Healing wound of a large cookie cutter shark (I. brasiliensis) bite (Photo M. Sakata).

Given that in the Marine Protected Area around Isla Guadalupe the fishing with gill nets is forbidden, and that there is no commercial vessel route close by that could cause death by intense sounds, we discarded the likelihood that the individual was incidentally killed by any of these situations. Also, the area where the stranding took place in the northeastern coast of Isla Guadalupe, is also where this species is often observed with 67 sightings by Cardenas-Hinojosa et al. (2009) and 28 by us (Gallo-Reynoso unpublished), and consists of a series of deep canyons that descend to the ocean floor. To know if the calf's death might be related to gas trauma, we found that adults of this species perform deep (863 to $2992 \mathrm{~m}$ ) and long (33 to $137.5 \mathrm{~min}$ ) dives (Tyack et al. 2006; Schorr et al. 2014), our data of measured dive times for adult Cuvier beaked whales at Isla Guadalupe, present a mean of $45.3 \pm 14 \mathrm{~min}$ (range: $30-59 \mathrm{~min}, n=28$; Gallo-Reynoso unpublished) well within the range mentioned above. No gas related trauma such as decompression could be confirmed due that we 
did not have the means to measure gas presence on epithelial tissues. Therefore a possible cause of the calf's death, which their lungs were found collapsed (in a probable apnea state), might be that the calf exceeded its aerobic diving limit during the ascent to the surface, which is slow in the species (Tyack et al. 2006; Schorr et al. 2014), the calf probably died by hypoxia.

Strandings of lone Cuvier's beaked whales have taken place in coastal areas of California and northeastern México (Bachara and Norman 2013). Massive strandings of this species are unusual (Heyning 1989). Over the last 20 years, several authors have suggested that some mass strandings of beaked whales are associated with naval military activities (Frantzis 2004; Martín et al. 2004, Rommel et al. 2006) or intense ship noise (Aguilar-Soto et al. 2006). According to Cox et al. (2006) the clarification of stranding causes is hampered by the lack of scientific knowledge on beaked whales, their physiology, behavior, distribution and habitat use.

\section{Acknowledgements}

We thank the crew of M / V Horizon (license 626408, San Diego, California) which helped us in all activities at Isla Guadalupe. We thank Japan Underwater Films that funded the expedition. Special thanks to M. Sakata for lending his photograph for the manuscript. We thank C. G. Zuno who helped us with the translation of the manuscript. This study was done with permits SGPA/ DGVS/01122/10 SEMARNAT (México) February 2010, and SGPA/DGVS/08330/10 SEMARNAT (México) October, 2010. Finally we thank W. Bachara, G. D’Elía and an anonymous reviewer for comments that significantly improved the manuscript.

\section{Resumen}

Introducción: Se encontró una cría varada de Zifio de Cuvier, Ziphius cavirostris, en la Isla Guadalupe, México, en donde esta especie ha sido observada con anterioridad.

Metodología: Se realizó una detallada necropsia para averiguar las posibles causas del varamiento. El individuo fue medido.

Resultados: La cría, una hembra, tenía una edad aproximada de un mes y se encontraba lactando. La temperatura corporal era aún normal, pero carecía de reacción pupilar y sin presencia de pulso arterial tomado en la parte interior del espiráculo y en las arterias mayores de los lóbulos caudales. Los estómagos contenían leche en diferentes estadíos de degradación (desde fresca hasta semi-digerida).

Discusión: La necropsia de la cría no mostró una indicación probable de su muerte, tal como heridas mayores por depredación, trauma, ulceras o infecciones aparentes, solo se notó la presencia de una efusión sanguínea burbujeante junto con algunos tejidos epiteliales y musculares extruidas por la apertura urogenital. No se pudo confirmar algún trauma relacionado con gases como la descompresión dado que no teníamos los medios para medir la presencia de gas en los diferentes tejidos. La probable cause de muerte fue por hipoxia.

Palabras clave: Isla Guadalupe, varamiento de cría; Zifio de Cuvier; Ziphius cavirostris.

\section{Literature cited}

Aguilar-Soto, N., Johnson M., Madsen P. T., Tyack P. L., Bocconcelli A., and Borsani J. F. 2006. Does intense ship noise disrupt foraging in deep-diving Cuvier's beaked whales (Ziphius cavirostris). Marine Mammal Science 22:690-699.

Bachara W., and S. A. Norman. 2013. Ziphius cavirostris strandings-a short review. Reports of the International Whaling Commission SC65/SM1.

Berdegué J. 1957. La Isla de Guadalupe, México. Contribución al conocimiento de sus recursos naturales renovables. Secretaría de Marina, Dirección General de Pesca e Industrias Conexas. Ciudad de México, México. 
Cox T. M., Ragen T. J., Read A. J., Vos E., Baird R. W., Balcomb K., Barlow J., Caldwell J., Cranford T., Crum L., D’Amico A., D’Spain G., Fernández A., Finneran J., Gentry R., Gerth W., Gulland F., Hildebrand J., Houser D., Hullar T., Jepson P. D., Ketten D., Macleod C. D., Miller P., Moore S., Mountain D., Palka D., Ponganis P., Rommel S., Rowles T., Taylor B., Tyack P., Wartzok D., Gisiner R., Mead J., and BenNer L. 2006. Understanding the impacts of anthropogenic sound on beaked whales. Journal of Cetacean Research and Management 7:177-187.

Cárdenas-Hinojosa G., Hoyos-Padilla M., and Rojas-Bracho L. 2012. Occurrence of Cuvier's Beaked Whales (Ziphius cavirostris) in Guadalupe Island, Baja California, México. International Whaling Commission SC/64/SM18.

Frantzis A. 2004. The first mass stranding that was associated with the use of active sonar (Kyparissiakos Gulf, Greece, 1996). Pp 14-20 in Proceedings of the Workshop on Active Sonar and Cetaceans held at the European Cetacean Society's 17th Annual Conference (Evans P. G. H., and L. A. Miller, eds). ECS Newsletter 42 (Special Issue).

Gallo-Reynoso J. P., and A. L. Figueroa-Carranza. 1992. A cookiecutter shark wound on a Guadalupe fur seal male. Marine Mammal Science 8:428-430.

Gallo-Reynoso J. P., and A. L. Figueroa-Carranza. 1995. Occurrence of bottlenose whales in the waters of Isla Guadalupe, Mexico. Marine Mammal Science 11:573-575.

Gallo-Reynoso J. P. and A. L. Figueroa-Carranza. 1998. Cetaceans of Isla de Guadalupe, Baja California, Mexico. Bulletin of the Southern California Academy of Sciences 97:33-38.

Gallo-Reynoso J. P., and A. L. Figueroa-Carranza. 2005a. Los Cetáceos de Isla Guadalupe. Pp 203-217 in Isla Guadalupe, restauración y conservación (Santos K., and E. Peters, comps.). Instituto Nacional de Ecología - SEMARNAT. Ciudad de México, México.

Gallo-Reynoso J. P., A. L. Figueroa-Carranza, and M. P. Blanco-Parra. 2005b. Los Tiburones de Isla Guadalupe. Pp 143-169 in Isla Guadalupe, restauración y conservación (Santos K.. and E. Peters, comps.). Instituto Nacional de Ecología - SEMARNAT. Ciudad de México, México, .

Gallo-Reynoso J. P., B. J. Le Boeuf A. L. Figueroa-Carranza, and M. O. Maravilla-Chávez. 2005c. Los Pinnípedos de Isla Guadalupe. Pp 171-201 in Isla Guadalupe, restauración y conservación (Santos K.. and E. Peters, comps.). Instituto Nacional de Ecología - SEMARNAT. Ciudad de México, México.

Heyning J. E. 1989. Curvier's beaked whales, Ziphius cavirostris G. Cuvier 1823. Pp 289-308 In Handbook of Marine Mammals, Volume 4: River dolphins and the larger toothed whales (Ridgway S. H., and R. Harrison, eds.). Academic Press. San Diego, USA.

Heyning J. E., And J. G. Mead. 2009. Cuvier's beaked whale, Ziphius cavirostris. Pp 294-295 in Encyclopedia of Marine Mammals (Perrin W. F., B. Würsig, and J. G. M. Thewissen, eds.). Academic Press. San Diego, USA.

Hoyos-Padilla M. E. 2009. Patrones de movimiento del tiburón blanco (Carcharodon carcharias) en Isla Guadalupe, México. PhD. thesis. Centro Interdisciplinario de Ciencias Marinas (CICIMAR). Instituto Politécnico Nacional. La Paz, Mexico.

Jones E. C. 1971. Isistius brasilensis, a squaloid shark, the probable cause of crater wounds on fishes and cetaceans. Fishery Bulletin 69:791-798.

Leatherwood S., R. R. Reeves, and L. Foster. 1983. The Sierra Club Handbook of whales and dolphins. Sierra Club Books. San Francisco, USA.

Lynn R. J., AND J. J. Simpson. 1987. The California Current system: the seasonal variability of its physical characteristics. Journal of Geophysical Research 92(c12):12,947-12,966.

Martín V., Servidio A. and S. Garcia. 2004. Mass strandings of beaked whales in the Canary Islands. Pp 3336 in Proceedings of the Workshop on Active Sonar and Cetaceans held at the European Cetacean Society's 17th Annual Conference (Evans P. G. H., and L. A. Miller, eds). ECS Newsletter 42 (Special Issue).

Pérez-Zayas J. J., A. A. Mignucci-Giannoni G. M. Toyos-González R. J. Rosario-Delestre, and E. H. Williams. 2002. Incidental predation by a largetooth cookiecutter shark on a Cuvier's beaked whale in Puerto Rico. Aquatic Mammals 28:308-311. 
Pierson M. O. 1987. Breeding behavior of the Guadalupe fur seal, Arctocephalus townsendi. Pp 83-94 in Status, Biology, and Ecology of fur seals (Croxall J. P., and R. L. Gentry, eds.). NOAA Technical Report NMFS 51.

Podesta M., And C. Meottı. 1991. The stomach contents of a Cuvier's Beaked whale Ziphius cavirostris, and a Risso's dolphin Grampus griseus, stranded in Italy. European Research on Cetaceans (Abstracts) 5:58-61.

Podesta M., A. D’Amico G. Pavan A. Drougas A. Komnenou, and N. Portunato. 2006. A review of Cuvier's beaked whale strandings in the Mediterranean Sea. Journal of Cetacean Research and Management 7:251-261.

Rommel S. A., Costidis A. M., Fernández A., Jepson P. D., Pabst D. A., Mclellan W. A., Houser D. S., Cranford T. W., Van Helden A. L., Allen D. M., And N. B. Barros. 2006. Elements of beaked whale anatomy and diving physiology and some hypothetical causes of sonar-related stranding. Journal of Cetacean Research and Management 7:189-209.

Schorr G. S., Falcone E. A., Moretti D. J., and R. D. Andrews. 2014. First Long-Term Behavioral Records from Cuvier's Beaked Whales (Ziphius cavirostris) Reveal Record-Breaking Dives. PLoS ONE 9,e92633.

Tyack P. L., Johnson M., Soto N. A., Sturlese A., And P. T. Madsen. 2006. Extreme diving of beaked whales. Journal of Experimental Biology 209:4238-4253.

Summited: February 20, 2014

Review: April 24, 2015

Accepted: May 11, 2015

Associated editor: Guillermo D'Elía 